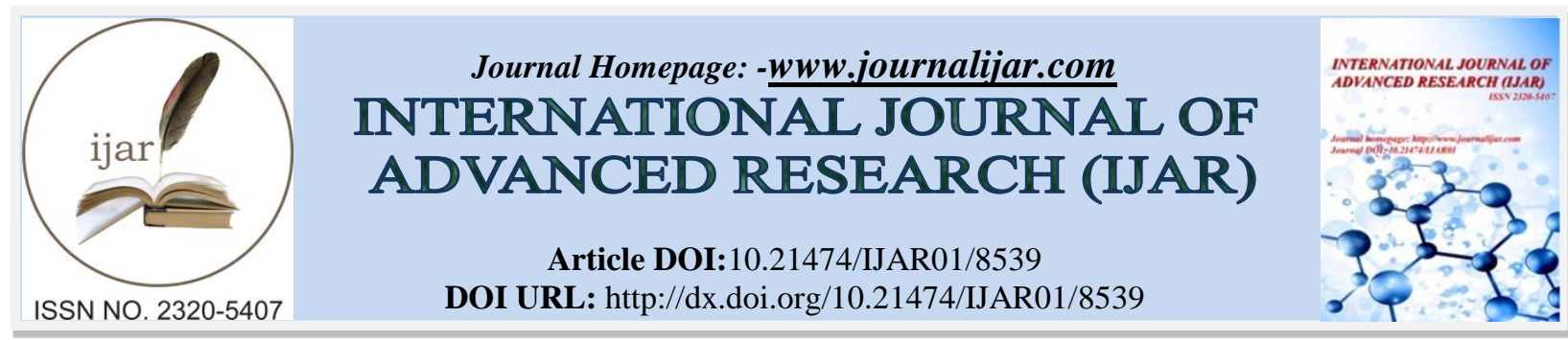

RESEARCH ARTICLE

\title{
AUTHORITY OF GOVERNMENT IN TRUST AND COMPLIANCE OF TAXPAYERS: THE THEORY OF SLIPPERY SLOPE.
}

\author{
Irawati.HM ${ }^{1}$, Muhammad Ali ${ }^{2}$, Yohanis Rura ${ }^{2}$ and Arifuddin ${ }^{2}$. \\ 1. STIM Publik Makassar, Indonesia. \\ 2. Faculty Of Economy, University Hasanuddin Makassar, Indonesia.
}

\section{Manuscript Info}

Manuscript History

Received: 11 December 2018

Final Accepted: 13 January 2019

Published: February 2019

Key words:-

government authority, taxpayer trust, tax compliance.

\begin{abstract}
Self-assessment system is a tax collection system that gives credence to the taxpayer to calculate, pay, and self-reported the amount of tax owed should have been based on legislation applicable tax. This study aims to analyze and determine the effect of the authority of the authority (authority) of tax and the trust of taxpayers directly and indirectly on taxpayer compliance at the Makassar Middle Tax Office with taxpayer trust as a moderating variable. This study uses 96 effective taxpayers in 2017 at the Makassar Middle Tax Office as a unit of research analysis. By using regression analysis, the results of this study show that government authority and trust in taxpayers have a positive effect on taxpayer compliance at the Makassar Middle Tax Office and the trustworthiness of taxpayers is able to moderate the relationship between government authorities and taxpayer compliance.
\end{abstract}

Copy Right, IJAR, 2019,. All rights reserved.

\section{Introduction:-}

The government's efforts to increase domestic revenues from the tax sector include changing the tax collection system from the official assessment system to the self-assessment system. This system change gives trust to the taxpayer to self-report the amount of tax that should be owed. In this self-assessment system, Taxpayers are given authority; trust; and the responsibility for calculating, calculating, paying, and reporting the amount of tax that must be paid for itself. The success of the self-assessment system will not be achieved without cooperation between tax officers and taxpayers. This system will run well if the community has a high level of awareness of voluntary tax compliance. Conversely, if the level of awareness of the taxpayer is still low, it will cause various kinds of problems (Cahyono, 2017).

The self-assessment system gives full trust to the taxpayers, even though they have been given facilities like this, there are still many people who do not carry out their tax obligations in accordance with the applicable tax provisions. This requires the government to intervene so that the tax arrears that occur can be repaid by the taxpayer. Based on the Law on General Provisions and Procedures for Taxation Article 45 paragraph (1) the Head of the Taxation Institution has the authority to conduct an assessment in the framework of carrying out supervision, Tax Examination, collection, or Tax Investigation. According to data obtained from the Ministry of Finance website (2015), the realization of 2014 tax revenues was Rp. 1,143.3 trillion or 74.37\% of total state revenue. Until August 31,2015 , the realization of tax revenues had reached Rp. 598,270 trillion. While according to the 2015 APBN-P the target for tax revenues is Rp. 1,294.258 trillion, the realization of tax revenues has reached $46.22 \%$. However, the

Corresponding Author:-Irawati.HM.

Address:-STIM Publik Makassar, Indonesia. 
results are not optimal, because it has not reached $65 \%$ of the total tax that must be received by the government (Directorate General of Taxes, 2015).

Meanwhile, the amount of tax revenue in the Makassar Middle Tax Office has not yet reached the target set by the government. Data obtained from the Makassar Middle Tax Office (2018) states the percentage of taxpayers and the amount of tax receipt tax obtained during the 5 (five) years namely 2013-2017 has decreased from $95.81 \%$ to $80.76 \%$, every year the realization in paying taxes has not yet reached the target set every year. In 2013 the realization amounted to $2,714,158,719,454$ but the principal was $2,832,834,668,115$, so in 2014 the realization was $2,945,663,327,392$, but the principal was $3,010,496,242,999$, in 2015 the realization was $3,483,153,210,464$, but the principal stipulation amounted to 4,086,359,104,997, in 2016 and 2017 the realization was 3,605,005,085,289 and decreased in 2017, which were 3,408,116,596,993, but the principal determination in 2016 was 4,230,549,999. 997 and 2017 amounting to 4,219,884,339,720 (Makassar Middle Tax Office, 2018). Realization of tax revenues decreased even though the target set was also lower when compared to the previous year.

According to Sari and Afriyanti (2012) research, noncompliance of taxpayers in the self-assessment system can develop if there is no firmness from the taxation agency. In order for the taxpayer to remain in the corridor of tax regulations, this can be anticipated by making efforts to intensify the examination of taxpayers who meet the criteria to be examined. Tax audits can have an impact on increasing tax receipts at the Tax Service Office (KPP), which ultimately taxes paid by taxpayers will be included in the state treasury. Not everyone wants to pay taxes and lots of gaps to manipulate taxes. Without intending to simplify, Indonesia's tax ratio, which is a comparison between tax revenues and gross domestic product, has not yet been optimally received. Indonesia only reached 12.1 percent, below Malaysia and Thailand which had reached 17 percent, or South Korea 24 percent, and OECD member countries by 34 percent (Yustinus Prastowo.2012). There are many reasons to explain this situation, two of which are still low public awareness to pay taxes and not yet the optimal performance of tax institutions. Why do tax institutions become objects in this case because the Directorate General of Taxes has very large and very strategic authority? The three elements in the taxation system are the center of attention, namely policy (tax policy), law (tax law), and administrative practice (practical tax administration) that need to be corrected.

According to the results of a Transparency International Indonesia survey on Indonesia's Corruption Perception Index in 2006, the Directorate General of Taxes was categorized as the most corrupt institution with an initiative to request bribes reaching 76 percent (LTRO Annual Report, 2004). In 2008, the Directorate General of Taxes was not included in the list of the most corrupt institutions in Indonesia. Furthermore, changes in people's perceptions of being good about taxes will be positively correlated with the level of compliance with paying taxes. As a result, the second indicator of success in achieving the tax revenue target is automatically fulfilled. As an illustration, in 2004, when the tax reform program began to run, the Directorate General of Taxes managed to collect tax revenues of Rp238.98 trillion and in 2008 the tax revenue realization had more than doubled, amounting to Rp.566.2 trillion. The realization of tax revenues which rose exponentially in the past 4 years is an accumulation of several factors, including the success of tax reforms.

Efforts to improve compliance and increase compliance and improve tax performance in Makassar City are continuously carried out by all tax offices in charge of each tax service office, both at the primary level and at the secondary level. Efforts to conduct a gradual inspection to increase the tax revenue ratio. In table 1, it shows that in 2013, 2014, it decreased by 16.10 percent and decreased by 21.36 percent in 2015, but towards the Tax Amnesty program. The tax audit then increased in 2016 and 2017 by 2.76 to 41.38 percent so that tax compliance was far more increased, and more state revenue in taxes was delayed. According to Friedland (1982) on the other hand, routine checks on taxpayers are carried out to improve tax compliance. The same thing also according to Wärneryd and Walerud (1982) because taxpayer checks found a significant positive relationship between the probability of tax audit and tax compliance.

Table 1:-Percentage of Tax Revenue Growth in 2013-2017 at Makassar Middle Tax Office

\begin{tabular}{|c|c|c|}
\hline Examination Year & Number of Examination Objects & Growth \\
\hline 2013 & 385 & - \\
\hline 2014 & 323 & $-16,10 \%$ \\
\hline 2015 & 254 & $-21,36 \%$ \\
\hline
\end{tabular}




\begin{tabular}{|c|c|c|}
\hline 2016 & 261 & $2,76 \%$ \\
\hline 2017 & 369 & $41,38 \%$ \\
\hline Total & $\mathbf{1 , 5 9 2}$ & - \\
\hline
\end{tabular}

Source: Makassar Middle Tax Office, 2018

Efforts to optimize tax revenues are by increasing taxpayer compliance. One of the factors that influence taxpayer compliance is the government's authority in taxation and the trust of taxpayers to the government. In the slippery slope of the Kirchler, Hoelzl, and Wahl (2008) framework, it was revealed that there are two main dimensions that influence tax compliance. These two dimensions are public trust in the tax authority and the authority of the tax authority itself. In this theory, it is assumed that tax compliance can be achieved by increasing the level of public trust and authority of the tax authority. The interaction between changes in the level of public trust and the authority of the tax authority is able to influence taxpayers in paying their taxes. By increasing the level or level of public trust and the strength of the tax authorities, it will increase tax compliance. Based on this description, this study aims to analyze and determine the effect of the authority of the tax authority and trust of taxpayers directly and indirectly on taxpayer compliance at the Makassar Middle Tax Office with the trust of taxpayers as a moderating variable.

\section{Background theory Theory of slippery slope}

In the slippery slope of the Kirchler, Hoelzl, and Wahl (2008) framework, it was revealed that there are two main dimensions that influence tax compliance. These two dimensions are public trust in the tax authority and the authority of the tax authority itself. In this theory, it is assumed that tax compliance can be achieved by increasing the level of public trust and authority of the tax authority. The interaction between changes in the level of public trust and the authority of the tax authority is able to influence taxpayers in paying their taxes. By increasing the level or level of public trust and the strength of the tax authorities, it will increase tax compliance.

Compliance conditions change when there is a change in the level of authority of the tax authority to a higher direction even though trust is at a low level. Opportunities for people to avoid taxes are smaller due to increased authority, resulting in an increase in tax compliance. However, this increase in compliance is not voluntary. The creation of forced compliance due to an increase in the authority of the tax authority that can be in the form of an increase in the number of checks and sanctions will make the public afraid of the legal consequences of tax evasion.

According to Kirchler, Hoelzl, and Wahl (2008), this theory integrates the results of research on the determinants of tax compliance not only from the economic side but also from the psychological side. The research paradigm regarding tax compliance is more likely to focus on the role of social and psychological (Wenzel 2004). The dimension of power or power of tax authorities is where the tax authorities can exercise their authority to detect tax violations and punish them either with sanctions or fines for tax violators. Whereas what is meant by the dimension of trust is public trust in the tax authorities which is influenced by justice perceived by the community, knowledge, and social norms.

\section{Dimension of Trust}

Trust is the foundation of business. A business transaction between two or more parties will occur if each trusts one another. These trusts cannot just be recognized by other parties or business partners, but must be built from the beginning and can be proven. Trusts have been considered as catalysts in various transactions between sellers and buyers so that customer satisfaction can be realized as expected (Yousafzai et al., 2003).

Trust is an important factor that can overcome crises and difficulties between organizations and customers. Besides that, it is also an important asset in building long-term relationships. Trust is a number specific to a belief in the integrity, honesty and the ability of the parties believed to keep the promise (Luarn and Lin, 2003: 156). Lowland trust in government and law trust is very important for good governance. Trust is an interpersonal relationship and the concept of a complex organization (Purnamasari, et al., (2016). According to Mardiasmo (2011) trust is a process of calculating (calculative process)between the costs incurred by the results obtained.

Trust is an important factor that can overcome crises and difficulties between organizations and customers. Besides that, it is also an important asset in building long-term relationships. Trust is a number of specific beliefs about integrity - honesty of the trusted party and the ability to keep promises (Luarn and Lin, 2003: 156). Factors that 
shape a person's belief against the other three, namely the ability (ability), goodwill (benevolence), and integrity (integrity) (Mayer et al. 1995). These three factors can be explained as follows.

Ability (Ability)

Kim and Tadisina (2003) state that abilities include competence, experience, institutional endorsement, and ability in science, (Coetzee and Eloff, 2005: 498).

\section{Good intentions ( Benevolence )}

Benevolence includes "attention, empathy, confidence, and acceptance". A person can act well because of belief. (Hoy and Tarter, 2004: 254) .

\section{Integrity (Integrity)}

Kim and Tadisina (2003) suggested that "integrity can be seen from the corner of fairness (fairness), fulfillment (fulfillment), fidelity (loyalty), frankness (honestly), the linkage (dependability), and reliability (reliability)". While integrity is honesty, fairness, and trust given to consumers (Koeszeig, 2004: 640).

Level of trust in government and law Instruments used to measure variables of trust in government and law according to Osman and Eren (2011). There are 3 (three) indicators, namely believing in the government's performance not abusing authority, finance being managed efficiently and transparently, and the government being fair to the people who commit violations.

\section{Dimensions of Government Authority in Taxation}

Tax is a mandatory contribution to the state-owned by an individual or entity that is compelling based on the Law, by not getting compensation directly and is used for state needs for the greatest prosperity of the people. (Article 1 paragraph 1, General Provisions Act and Tax Procedures). Based on the Law on General Provisions and Procedures for Taxation Article 45 paragraph (1) the Head of the Taxation Agency has the authority to conduct assessments in order to carry out supervision, tax audit, collection, or tax investigation. The self-assessment system gives full confidence to the taxpayer community to calculate, calculate, deposit and report their own tax. Even though it has been given convenience like this, there are still many people who do not carry out taxation obligations in accordance with applicable tax provisions. This requires the government to intervene so that the tax arrears that occur can be repaid by the taxpayer. The way that is done by the government is by collecting taxes. The legal basis for tax collection in Indonesia is regulated in Article 18 of Article 24 of Law KUP and in Law Number 19 of 1997 concerning Tax Collection with Forced Letter d.dt.d Law Number 19 the Year 2000. Tax collection is divided into 2 groups, namely passive billing, and active collection. In passive tax collection, the tax authority only issues tax bills or tax assessments without further action. While active billing is a follow-up of passive billing with the active action of tax authorities in collecting tax debts. While Tax Payables are accrued taxes including administrative sanctions in the form of interest, fines or increases stated in a tax assessment letter or similar letter based on the provisions of tax laws and regulations. (Article 1 number 8 of Law No.19 of 2000), including the seizure of property of taxpayers is to block accounts in banks.

Kirchler et al., ( 2008) in the theory of slippery slope suggests that tax authorities that have legitimate power, treat taxpayers as equal partners and promote themselves as advisors in implementing tax laws, then taxpayers will trust tax authorities and respond with a return that is compliance. Legitimate authority should be able to increase confidence by providing satisfactory services to the taxpayer because it will lead to voluntary compliance.

Eva Hofmann, et al. (2014) in his journal entitled Enhancing Tax Compliance Through Coercive and Legitimate Power of Authorities states that there are two factors that can affect taxpayers to pay taxes honestly, namely coercive power and legitimate power. Coercive power is carried out in positive good ways through the existence of objections and appeals for each taxpayer and negative through the application of sanctions for late SPT submission, tax payments, confiscations, and bans as well. While legitimate power is built through methods such as increasing the reputation of the tax authority (in this case the Directorate General of Taxes), increasing taxation tax authorities, information disclosure and increasing the frequency of tax socialization.

\section{Tax Compliance}

Alm et al (1990) tax Compliance or tax compliance are defined as the ideal condition of taxpayers who meet tax regulations and report their income accurately and honestly. From these ideal conditions, tax compliance is defined as a state of taxpayers who fulfill all tax obligations and carry out their taxation rights in the form of formal and 
material compliance. The concept of tax compliance above is in accordance with the opinion that states the level of voluntary tax compliance has three aspects, namely the formal, material ( honestly), and reporting ( reporting ). The level of taxpayer compliance is influenced by factors such as the amount of income, tax rates, perceptions of taxpayers on the use of tax money, taxation treatment, implementation of law enforcement, heavy (mild) tax sanctions and the completeness and accuracy of databases.

According to Bradley (1994), the notion of tax compliance ( tax compliance) is the taxpayer has a willingness to fulfill his tax obligations. Fulfillment of tax obligations must be in accordance with applicable regulations without the need for checks, obtrusive investigation, warnings, threats, and the application of legal and administrative sanctions. Compliance with taxpayers in fulfilling their tax obligations will increase state revenues and in turn, increase the size of the tax ratio. Tax compliance can be defined as the extent to which taxpayers fulfill or fail to comply with their state tax rules (Marziana et al, 2010). The purpose of tax administration efficiency is to encourage voluntary tax compliance using all possible tax collection methods including fines. In the tax compliance literature, the taxpayer's perception of justice from the tax system is recognized as an important factor has a significant influence on tax compliance behavior. Taxpayer perceptions are closely related to knowledge and experience, so awareness of tax issues and tax knowledge affects the level of tax compliance. Rusdi et al (2014) tax is the tax function's behavior as a constellation of cognitive, effective and conative interacting in understanding, feel and behave towards the meaning and function of taxes. Therefore, Encouraging taxpayer compliance and the success of tax revenues.

Power in authority is meant here is the tax authority to detect and punish tax crimes (Kirchler et al. 2008). If the authority of the government has a low power to control tax evasion in a society it might reduce public trust in the government. The government is believed to be able to protect honest taxpayers from free exploitation. Power to combat tax evasion can increase trust through cooperative behavior (Mulder et .al, 2006). On the one hand, power can encourage trust, while on the other hand, it can also damage trust, depending on the climate of interaction between taxpayers and tax authorities. Changes in one dimension may have different consequences in other dimensions. For example, an increase in government power is interpreted by honest taxpayers as a sign of distrust of government authority and thus can damage their motivation to fulfill their tax obligations ( Frey, 1997; Feld and Frey, 2007). On the other hand, honest taxpayers might interpret the impulse in power as a government effort to reduce tax avoidance, so that it can increase the confidence of taxpayers in the authority and increase the level of compliance.

Legitimate power is not based on pressure and coercion but on legitimacy, knowledge, ability, and identification with power. The legitimacy, knowledge, and abilities of the tax authorities lead to success in carrying out their work and encourage trust (Gangl et al ., 2012). Widodo (2010: 284) states that improving service quality and quantity is expected to increase satisfaction with taxpayers so as to encourage compliance in the taxation field. According to the research of Dewi and Widuri (2013), there are several factors that influence the level of taxpayer compliance, including environmental conditions that do not comply with taxes, disappointing tax authorities services, tax rates that are considered too high, and a poor tax administration system. The Office of Revenue and Finance must make efforts to improve the quality and quantity of services that are expected to increase satisfaction to taxpayers as customers so that the perception of taxpayers facing service quality will be positive.

Cahyono's (2017) research shows that the level of understanding of service quality perceptions influences tax revenue. This means that the perception of service quality has the ability to influence tax revenue. Efforts in increasing tax revenues can be done by increasing the quality of good service to taxpayers. Improving service quality can be done by improving the quality and technical capabilities of employees in the field of taxation, infrastructure improvements such as the expansion of integrated service areas (TPT), use of information systems and technology that can provide taxpayers with ease in fulfilling their tax obligations. The better the perception of taxpayers on the quality of service, the higher the level of tax revenue. Service quality is a level of excellence to fulfill the desires of taxpayers. Service quality can be assessed based on taxpayer perceptions by comparing expectations when receiving services with real experience of services received.

The theory of slippery slope argues that the more developed moral reasoning is more likely to be related to voluntary tax compliance. By definition, the purpose of the tax is for the greatest prosperity of the people (Kirchler et al, 2008). In accordance with the research stated by Togler and Scheinder (2004) the level of trust has a positive effect on Austrian tax morale and the level of compliance is largely determined by the taxpayer's moral taxation. 
Mandatory $\mathrm{p}$ invite who believe the government showed high adherence rates compared with non-believers. This is in line with what was conveyed by Scholz and Lubell (1998), the level of trust in taxpayers in America against the government determines the level of compliance. Thus the confidence of individuals, in this case, the taxpayer influences the drive to commit and comply with the applicable regulations.

Pratomo (2014) revealed that the level of trust in the system of government and law has an effect on compliance with paying taxes. If the community does not believe in the government mechanism, then the awareness of paying taxes will also be low. The results of the study by Hakim et al(2017) show that procedural justice and moral obligations are related to voluntary tax compliance. The results of this study also indicate that the mediating role of taxpayer trust. Voluntary compliance with taxes occurs because procedural justice and moral obligations lead to voluntary compliance through mediation mechanisms of taxpayer trust, and the relationship between taxpayer trust and taxpayer voluntary compliance is not moderated by legitimacy. Sellywati et al (2017) suggested the relationship between trust influences tax compliance actions and also has a relationship with the element of justice. the results of this study indicate that taxpayer trust is able to influence tax compliance in Malaysia.

Kastlunger et al., ( 2013) found empirical evidence that legitimacy power has a positive effect on trust in the tax authorities in increasing voluntary compliance of taxpayers. Ratmono and Cahyonowati, 2013. In his research, he showed that tax compliance is still determined by economic variables such as the possibility of tax audits and tax penalties. Taxpayers tend to have a high level of compliance if they are likely to be audited by the tax authorities and subject to high penalties for tax violations.

Tenbrunsel and Messick (1999) found that the effect of the level of sanctions on compliance depends (moderated) by the perceived probability that the offender will be caught committing a violation by the authorities. Mulder (2009) found that sanctions levels can improve moral concerns about unethical behavior if authorities are trusted. Wenzel (2004) found that the level of sanctions has an effect on compliance for people who believe that paying taxes is ethical behavior.

Research on the level of tax penalties is also important from a theoretical perspective because the results of the study show conflicting empirical evidence. The question of why a high level of tax fines can increase compliance is still an important research issue (Verboon and van Dijke, 2011). There are two perspectives in the tax behavior literature why fines and tax audits can affect compliance. The instrumental perspective states that it is sometimes advantageous to disobey the rules if the sanctions imposed on these violations are smaller than the benefits derived from committing a violation. Therefore, the instrumental perspective emphasizes that the level of sanctions must outweigh the benefits of conducting payments (Allingham and Sandmo, 1972; Carroll, 1978 ).

The level of trust in the government and the law does not affect the compliance with paying taxes, due to the existence of taxpayers who have not trusted the government apparatus and the legal system that is running. When associated with the theory of reasoned action, humans will behave in ways that are aware of and consider the information available, and consider the implications of the actions taken (Wijayanti and Noer, 2017). Taxpayers feel that by considering existing information, such as the amount of reporting on the use of funds that are not appropriate, cases of corruption, tax evasion cases, and various other cases related to injustices in the legal system that are running. Where it makes taxpayers think in a rational way that the tax paid to the state is not used as well as possible for people's welfare so that a sense of lack of trust in taxpayers arises and influences the behavior of taxpayers to act disobediently in paying.

Based on the results of research conducted by Ratmono and Cahyonowati, (2013) the variable of trust in government authority affects the level of tax compliance more than the examination variables and tax penalties. Therefore, in the long term, it is very important for the government to increase public trust in the legal and taxation system because this variable can increase intrinsic motivation to comply with tax regulations. The importance of the trust variable on the tax authority also shows the support of the theory of slippery slope that the dimensions of trust in authorities play an important role in increasing voluntary tax compliance (Kirchler et al., 2008). Using analysis from 25 countries in Europe, the results of the Stefanos (2017) study show that trust and strength are positively correlated with higher tax compliance. Trust and strength also moderate one another: lower trust, the greater the impact of compliance with increased power. However, the positive effect decreases with increasing coercion. Strong prevention policies can ultimately damage tax compliance. 


\section{Research And Conceptual Framework For Research}

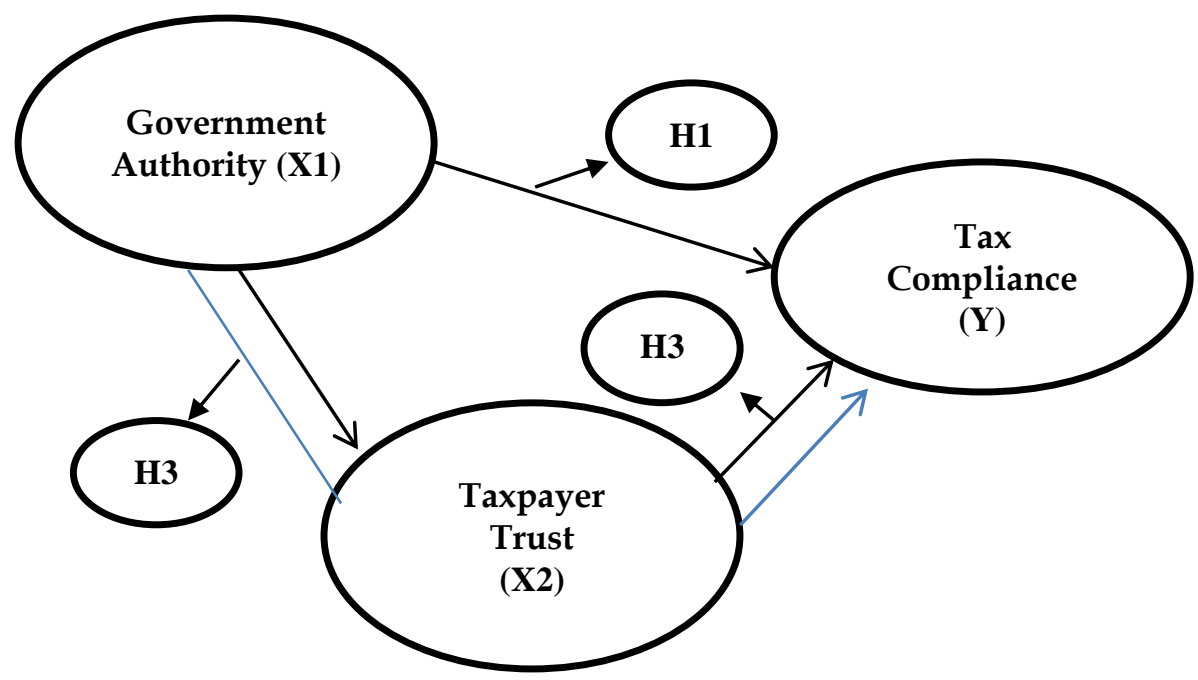

Figure 1. Conceptual Framework

\begin{tabular}{|l|l|}
\hline H 1 & Government authority in taxation has a positive effect on tax compliance \\
\hline & $\begin{array}{l}\text { Based on the results of the study of Kastlunger } \text { et al. (2013), Ratmono and Cahyonowati } \\
\text { (2013), Tenbrunsel and Messick (1999), Mulder (2009), Wenzel (2004), (Verboon and van Dijke, 2011), } \\
\text { (Allingham and Sandmo, 1972; Carroll, 1978). }\end{array}$ \\
\hline H2 & Taxpayer trust has a positive effect on taxpayer compliance \\
\hline H 3 & $\begin{array}{l}\text { Based on the results of the study (Kirchler et al, 2008), Togler and Scheinder (2004), Scholz and Lubell } \\
\text { (1998), Pratomo (2014), Hakim } \text { et al (2017), Sellywati } \text { et al (2017), Widodo (2010: 284), Dewi and Widuri } \\
\text { (2013), Cahyono (2017). } \\
\text { Taxpayer's trust is able to moderate the relationship of government authority in taxation to taxpayer } \\
\text { compliance }\end{array}$ \\
\hline $\begin{array}{l}\text { Based on the results of the study (Wijayanti and Noer, 2017), Ratmono and Cahyonowati, (2013), (Kirchler } e t \\
\text { al ., 2008) and Stefanos (2017). }\end{array}$ \\
\hline
\end{tabular}

\section{Research Methods:-}

Efforts to optimize tax revenues are by increasing taxpayer compliance. One of the factors that influence taxpayer compliance is the government's authority in taxation and the trust of taxpayers to the government. In the slippery slope of the Kirchler, Hoelzl, and Wahl (2008) framework, it was revealed that there are two main dimensions that influence tax compliance. These two dimensions are public trust in the tax authority and the authority of the tax authority itself. In this theory, it is assumed that tax compliance can be achieved by increasing the level of public trust and authority of the tax authority. The interaction between changes in the level of public trust and the authority of the tax authority is able to influence taxpayers in paying their taxes. By increasing the level or level of public trust and the strength of the tax authorities, it will increase tax compliance.

\section{Research Location}

This research is located at the Makassar Middle Tax Office, Jl. Urip Sumoharjo KM.4, Pampang, Panakkukang, Makassar City, South Sulawesi, Indonesia.

\section{Population and Samples}

The population in this study were all effective taxpayers registered Makassar Middle Tax Office totaling 2,040 taxpayers. Because the population is known as 2,040 effective taxpayers in 2017 at the Makassar City KPP, the determination of the number of samples is determined according to the Slovin model (Umar, 2002: 78) in Leni (2013).

$\mathrm{n}=\frac{N}{1+N E^{2}} \quad \mathrm{n}=\frac{N}{1+N E^{2}} \mathrm{n}=\quad 2.040$ 


$$
\begin{aligned}
& 1+(2.040)(0,1) \\
& \mathrm{n}=\frac{2.040}{21,4}=96 \text { respondents }
\end{aligned}
$$

This research uses 96 respondents as the unit of analysis in research, in order to get more accurate data in accordance with the first rule. The larger the sample taken in the study, the better the results of the study will be.

\section{Data Analysis Method:-}

The analysis was carried out using the analysis method as follows:

\section{Descriptive Analysis}

Descriptive analysis is intended to provide a general picture of the object studied through sample data or population as it is, without analyzing and making conclusions that apply in general. The data obtained through the results of this descriptive analysis is done by presenting it in the form of a regular table or through a frequency distribution table.

\section{Analysis of Multiple Linear Regression}

Adjusting to the objectives of the study, the data analysis technique used in this study is multiple linear regression analysis. This analysis is used to determine the effect of independent variables on the dependent variable. To determine there is a significant effect between the independent variables on the dependent variable, the regression coefficient statistical test is used. The following linear regression model (Sugiyono, 2012: 183) is:

$$
\begin{gathered}
Y_{1}=b_{0}+b_{1} X_{1}+b_{2} X_{2}+e \\
Y_{2}=b_{0}+b_{1} X_{1}+b_{2} X_{2}+b_{3} X_{1} X_{2}+e
\end{gathered}
$$

Description:

$$
\begin{aligned}
& Y=\text { Taxpayer Compliance } \\
& X 1=\text { Government Authority } \\
& \text { X } 2=\text { Community Trust } \\
& \text { b0 = constant } \\
& \text { b1, b2 and b3 = regression coefficient } \\
& \text { e }=\text { standard error. }
\end{aligned}
$$

To find out whether there is a relationship between independent variables and non-independent variables simultaneously, it can be seen the results of multiple R correlation coefficient test while the level of influence can be seen the test results of the coefficient of determination R2. The significance of the influence can be seen from the results of the F-Test and the probability level with a confidence level of $95 \%$ or $\alpha=0.05$. If Test - F> F - table and probability $<\alpha 0.05$ then there is influence, so the null hypothesis (HO) is rejected and alternative hypothesis (Ha) is accepted, then, if Test - F $<\mathrm{F}$ - table and probability $>\alpha 0,05$ then there is no influence then the null hypothesis (Ho) is accepted and the alternative hypothesis $(\mathrm{Ha})$ is rejected.

In addition, a t-test (student-test) can also be carried out to determine the effect of each independent variable partially on its non-independent variables with a confidence level of $95 \%$ or $\alpha=0.05$. If the Test $-\mathrm{t}>\mathrm{t}-$ table and probability $<\alpha 0.05$ then there is an effect so that the null hypothesis (HO) is rejected and the alternative hypothesis (Ha) is accepted. Furthermore, if the test $=\mathrm{t}<\mathrm{t}=$ probability table $>\alpha 0.05$ then there is no influence, so the null hypothesis (Ho) is accepted and the hypothesis $(\mathrm{Ha})$ is rejected.

\section{Research Results And Discussion:- \\ Research result}

T-Test (Partial)

To test the regression coefficient partially tested to see the significance of the effect of each variable.

Table 2:-Coefficients

\begin{tabular}{|l|l|c|c|c|c|c|}
\hline \multicolumn{2}{|l|}{ Model } & \multicolumn{2}{c|}{$\begin{array}{c}\text { Unstandardized } \\
\text { Coefficients }\end{array}$} & \multirow{2}{*}{$\begin{array}{c}\text { Standardized } \\
\text { Coefficients }\end{array}$} & \multirow{2}{*}{ Sig. } & \\
\cline { 3 - 7 } \multicolumn{2}{|l}{} & B & Std. Error & Beta & & \\
\hline \multirow{2}{*}{1} & (Constant) & 1.425 & .558 & & 2.555 & .012 \\
\cline { 2 - 7 } & Government Authority & .229 & .1010 & .198 & 2.087 & .40 \\
\cline { 2 - 7 } & Taxpayer Trust & .401 & .099 & .386 & 4.064 & .000 \\
\hline
\end{tabular}


Source: Primary data processed in 2018

By using multiple regression analysis in the above analysis, the following equations are obtained:

1. A constant of 1,425 states that if the authority of the government and the trust of the taxpayer are considered constant, then taxpayer compliance is 1,425 .

2. The government authority regression coefficient of 0.229 indicates that the influence of government authority on taxpayer compliance is positive with an effect of $22.9 \%$. Based on the regression coefficient value, it can be concluded that government authority has a significant influence on taxpayer compliance at the Makassar Middle Tax Office with a significance level of 0.040 .

3. The taxpayer trust regression coefficient of 0.401 indicates that the effect of mandatory trust in taxpayer compliance at the Makassar Middle Tax Office is positive with an influence of $40 \%$. and a significance level of 0,000 .

F Test (Significant)

Table 3:-ANOVA ${ }^{\mathrm{b}}$

\begin{tabular}{|l|l|r|r|r|r|r|}
\hline \multicolumn{2}{|l|}{ Model } & Sum of Squares & df & Mean Square & F & \multicolumn{1}{c|}{ Sig. } \\
\hline \multirow{3}{*}{1} & Regression & 6,940 & 2 & 3,470 & 13,996 & $.000^{\mathrm{a}}$ \\
\cline { 2 - 7 } & Residual & 23,060 & 93 & .248 & & \\
\cline { 2 - 7 } & Total & 30,000 & 95 & & & \\
\hline
\end{tabular}

Source: Primary data processed in 2018

The ANOVA table is used to test whether all the independent variables together have a significant effect on the dependent variable. Basic decision making with a significance level of alpha 5\% with the following conditions: (a) If Fcount $>$ Ftable, then H1 is accepted. (b) If Fcount <Ftable, then H1 is rejected. Based on the results of the analysts, it shows that with the expectation of signification of 0.000 which shows that the authority of the government and the trust of the taxpayer jointly influence the taxpayer compliance in the Makassar Middle Tax Office.

The coefficient of Determination.

Table 4:-First Regression Output Summary Model

\begin{tabular}{|l|c|r|r|r|}
\hline Model & $\mathrm{R}$ & R Square & Adjusted R Square & Std. An error of the Estimate \\
\hline 1 & $.481^{\mathrm{a}}$ & .231 & & .215 \\
\hline
\end{tabular}

Source: Primary data processed in 2018

Table 5:-Second Summary Regression Output Model

\begin{tabular}{|l|c|c|cc|c|}
\hline Model & $\mathrm{R}$ & R Square & Adjusted R Square & Std. An error of the Estimate \\
\hline 1 & $.819^{\mathrm{a}}$ & .671 & .660 & .32766 \\
\hline
\end{tabular}

According to the table output the first regression and the output of the second regression $\mathrm{n}$ use values of $\mathrm{R} 2$ in the first regression or 0.231 or $23.1 \%$, while after the regression equation both R2 rose to 0,671 or $67.1 \%$. By looking at the results above, it can be concluded that with the variable taxpayer trust (moderating variable) will be able to strengthen the relationship of government authority to taxpayer compliance.

\section{Discussion:-}

Based on the results of the analysis of the study, the discussion was carried out by describing the strong influence of exogenous variables consisting of: This study raised the government's authority variable (X1), taxpayer's trust (X2) and taxpayer compliance (Y) on some taxpayers and several descriptions taxpayer characteristics at the Makassar Middle Tax Office which is the unit of analysis. Description of the strength of influence between variables, when compared with empirical evidence obtained in the field, and theories that support the hypothesis. The following stages of discussion are based on the path of the relationship between variables in the model:

\section{Government authority has a positive effect on tax compliance}

The results of the study show that government authority has a positive effect on taxpayer compliance. this shows that government authority has the legal power to conduct checks and issue forced letters, so this condition forces 
taxpayers to carry out their tax obligations. Compliance with taxpayers is the key to success for tax revenue using the self-assessment system collection system. In the self-assessment system, taxpayers will be given the trust to calculate, deposit and report the amount of tax payable. So that in this system there is a shift of responsibility from the tax authorities to taxpayers. The fiscal duty is only to oversee the implementation of taxpayers' tax obligations by carrying out checks on taxpayer compliance with applicable tax laws and regulations.

In line with the results of research by Allingham and Sandmo, (1972); Carroll, (1978), Tenbrunsel and Messick (1999), Mulder (2000), Kastlunger et al., (2013) Ratmono and Cahyonowati, (2013) in their research results show that tax compliance is still determined by economic variables such as the possibility of tax audits and tax penalties. Taxpayers tend to have a high level of compliance if they are likely to be audited or audited by the tax authorities and subject to high penalties for tax violations. Consistent with (Verboon and van Dijke, 2011) found that the effect of the level of sanctions on compliance. Wenzel (2004) found that the level of sanctions has an effect on compliance for people who believe that paying taxes is ethical behavior. Consistent with the research of Verboon and van Dijke, 2011). There are two perspectives in the tax behavior literature why fines and tax audits can affect compliance.

\section{Taxpayer trust has a positive effect on taxpayer compliance}

Taxpayer trust has a positive effect on taxpayer compliance. This shows that if the community believes in the government, they will be more likely to cooperate in paying taxes and vice versa if the community does not believe in the government tax mechanism, then the awareness of paying taxes will also be low. In the self-assumption system there is full trust in the taxpayer to conduct a self-assessment giving severe consequences for taxpayers, meaning that if the taxpayer does not fulfill the tax obligations borne by him, the sanctions imposed will be more severe. Therefore the self-assessment system requires taxpayers to further explore the applicable tax laws so that taxpayers can carry out their tax obligations properly.

In line with the research of Hakim et al (2017), Sellywati et al (2017), Togler and Scheinder (2004) the level of trust has a positive effect on the level of compliance. This is in line with what was conveyed by Scholz and Lubell (1998), the level of taxpayers' trust in America towards the government determines the level of compliance. Consistent with the results of the Pratomo study (2014) revealed that the level of trust in the system of government and law has an effect on compliance with paying taxes. If the community does not believe in the government mechanism, then the awareness of paying taxes will also be low. Consistent with Pratomo (2014), Hakim et al (2017), Sellywati et al (2017), Togler and Scheinder (2004) the level of trust has a positive effect on taxpayer compliance. This is in line with what was conveyed by Scholz and Lubell (1998), the level of trust in taxpayers in America against the government determines the level of compliance. But it is different from the results of research (Wijayanti and Noer, 2017). the level of trust in the government and the law does not affect the compliance with paying taxes, due to the existence of taxpayers who have not trusted the government apparatus and the legal system that is running.

\section{Taxpayer's trust is able to moderate the relationship of government authority in taxation to taxpayer compliance}

The trust of taxpayers is able to moderate the relationship between government authority and taxation. Perception of public trust in government authority in the applicable taxation system will affect the implementation of good taxation in the country. Community trust as a taxpayer will affect the level of tax compliance behavior and tax avoidance behavior, the community will not obey and avoid their tax obligations if they feel that the tax system applies unfairly.

Consistent with the results of the study by Kastlunger et al. (2013), (Verboon and van Dijke, 2011), Mulder (2009), (Allingham and Sandmo, 1972), Mulder et.al, 2006). (Frey, 1997; Feld and Frey, 2007). (Gangl et al., 2012), Widodo (2010), Dewi and Widuri (2013) and the results of research by Cahyono (2017), Carroll, 1978) found empirical evidence that government authority influences taxpayer compliance. consistent with the results of research conducted by Ratmono and Cahyonowati, 2013, the possibility of tax audits of tax sanctions and penalties will make taxpayers tend to have a high level of compliance if they are likely to be audited or audited by the tax authorities and subject to high penalties for tax violations.

Government authority is the tax authority to detect and punish tax crimes (Kirchler et.al 2008). If the authority of the government has a low power to control tax evasion in a society it might reduce public trust in the government. The 
government is believed to be able to protect honest taxpayers from free exploitation. Power to combat tax evasion can increase trust through cooperative behavior (Mulder et.al, 2006).

\section{Theoretical Contributions to Research Results}

In this study using variables that have been studied by several previous researchers. The analysis in this study examines the influence of variables that influence taxpayer compliance to carry out their tax obligations at the Makassar Middle Tax Office, for that to be considered as a contribution in this study: the results of this study support the Slippery Slope Framework theory proposed by Kirchler trying to combine factors economic and noneconomic. Slippery Slope Framework states that the level of public trust in the tax authority and the level of authority of the tax authority can affect tax compliance. If the tax authorities and taxpayers have mutual trust, then it can lead to a synergistic climate. Conversely, if there is no trust between the tax authorities and taxpayers there will be an antagonistic tax climate (Kirchler, Hoelzl, and Wahl, 2008). According to the framework, citizen tax compliance can be fostered either through increasing trust in authority or by increasing perceptions of the power of authority. However, the quality of compliance is different, depending on the basis of honest taxpayers. Increasing tax honesty through increasing government trust leads to voluntary compliance while increasing authority and creating compliance. The results of this study support the assumption of the slippery slope while confirming the role of trust and power as determinants of tax compliance.

\section{Conclusions And Suggestions:- Conclusion}

1. Government authority has a positive effect on tax compliance. this shows that government authority has the legal power to compel taxpayers to carry out their tax obligations.

2. Taxpayer trust has a positive effect on taxpayer compliance. this shows that if the community believes in the government, they will be more likely to cooperate in paying taxes and vice versa.

3. Perception of public trust in government authority in the applicable tax system will affect taxpayer compliance and tax avoidance behavior, the community will not obey and avoid their tax obligations if they feel that the tax system applies unfairly.

\section{Suggestion}

1. Makassar Middle Tax Office should carry out tax counseling activities that are more effective and efficient to socialize the taxation system to the community to increase public trust in taxation.

2. Government authority influences taxpayer compliance, therefore the tax authorities should be able to increase public trust by providing satisfactory services to taxpayers because it will lead to voluntary compliance.

3. We recommend that measurement of variables other than by using a questionnaire needs to be strengthened by direct interviews with tax employees so that the data obtained will be more valid.

\section{Bibliography:-}

1. Alm, James; Roy Bahl: Matthew N. Murray, 1990. Tax Structure and Tax Compliance. The Review of Economics and Statistics. Vol. 72, No. 4. (November), pp. 603-613.

2. Allingham, M.G. and Sandmo, A. 1972. Income Tax Evasion: A Theoretical Analysis. Journal of Public Economics 1 (3) pp. 323-338.

3. Basri Yesi Mutia. 2013. Trust and Power in Government Authority as Determinants of Tax Compliance Levels and Tax Evasion: Testing Assumptions for the Slippery Slope Framework. , Riau University.

4. Bradley, Cassie Francies. 1994. An Empirical Investigation of Factor Affecting Corporate Tax Compliance Behavior. Dissertation. The University of Alabama, USA.

5. Carroll, J. S. 1978. A psychological approach to deterrence: The evaluation of crime opportunities. Journal of Personality and Social Psychology, 36, 1512-1520.

6. Cahyono, Yuli Tri. 2017. Analysis of Factors Affecting Tax Receipts (Empirical Study in Surakarta Pratama Tax Service Office). Indonesian Accounting and Financial Research, 2 (2), 2017. Pages 163-175.

7. Dewi, Olivia, and Retnaningtyas Widuri. 2013. "Factors that influence the success of local tax revenues in the city of Tarakan." Journal of Economics No. 2, Vol 3.

8. Frey, B. S. 1997. Not just for the money: An economic theory of personal motivation. Cheltenham: Edward Elgar.

9. Feld, L. P., and Frey, B. S. 2007. Tax compliance as a result of a psychological tax contract: The role of incentives and responsive regulation. Journal Law and Policy, 29, 102-120. 
10. Gangl, K., Hofmann, E., Pollai, M., and Kirchler, E. 2012. The dynamics of power and trust in the Slippery Slope Framework and its impact on the tax climate.

11. Gunadi, 2002. Indonesian Taxation 2002; A Reference Guide. Jakarta: Multi Utama Publishing.

12. Judge, Zulkarnain, Lilik Handajani, and Biana Adha Inapty. 2017. Hospitality Company Taxpayer Voluntary Tax Compliance: Determinants, Trust and Legitimacy Power. Journal of Accounting / Volume XXI, No. 02, May 2017: 253-277.

13. Hofmann, Eva, Katharina, G., Erich, K., and. Jennifer, S. 2014. "Enhancing Tax Compliance Through Coercive And Legitimate Power of Tax Authorities by Concurrently Finishing or Facilitating Trust In Tax Authorities". Law and Policy, 36 (3).

14. Hoy, W.K. and Tarter, C.J. 2004. Organizational justice in schools: no justice without trust. International Journal of Educational Management; 18 (4): 250-259.

15. Mardiasmo. 2011. Taxation. Yogyakarta: Andi.

16. Kastlunger, B., Edoardo, L., Erich, K., and Alfred, S. 2013 "Powerful Authorities And Trusting Citizens: The Slippery Slope Framework and Tax Compliance in Italy". Journal Of Economic Psychology, 34, 36-45.

17. Kim, E., and Tadisina, S., 2003. Customer's Initial Trust in E-Business: How to Measure Customer's Initial Trust, Proceedings of the Ninth Americas Conference on Information Systems, pp. 35-41.

18. Kirchler, E., Erik H., and Ingrid W. 2008. "Enforced Versus Tax Compliance Voluntary: The" Slippery Slope "Framework". Journal of Economic Psychology, 29, 210-225.

19. Kogler C, Batrancea L, Nichita A, Jozsef P d, Alexis B e, Kirchler E. 2013. Journal of Economic Psychology 34 (2013) 169-180 2013. The trust and power of tax compliance: Testing of assumptions of the slippery slope framework in Austria, Hungary, Romania, and Russia.

20. Outside, Pin. and Hsin-Hui Lin. 2003. A customer Loyalty Model for E-Service Context. Journal of Electronic Commerce Research, Vol. 4: 156 - 167.

21. Lohmoller JB. 1989. Latent Variable Path Modeling with Partial Least Squares. (Physica, Heidelberg.).

22. Mulder, L. B., van Dijk, E., De Cremer, D., and Wilke, H. A. M. 2006. Undermining trust and cooperation: The paradox of sanctioning systems in social dilemmas. Journal of Experimental Social Psychology, 42, 147-162.

23. Mulder, L. B., Verboon, P., and De Cremer, D. 2009. Sanctions and moral judgment: The moderating effect of sanction severity and trust in authorities. European Journal of Social Psychology, 39, 255-269.

24. Mayer, R.C., Davis, J. H., and Schoorman, F. D., 1995. An Integrative Model of Organizational Trust, Academy of Management Review, 30 (3): 709-734.

25. Osman Fatih and Eren Caskurlu. 2011. Tax Amnesty with Effects and Effecting Aspects: Tax Compliance, Tax Audits, and Enforcement Around; The Turkish Case. International Journal of Business and Social Science. Vol. 2 No. 7. Page. 95-105.

26. Pratomo, Aloysius Brian. 2014. Influence of Awareness, Knowledge, Perception, Level of Trust in Willing to Pay Taxes: A Case Study of Personal Taxpayers at Pratama Tax Service Office (KPP), East Semarang. Abstract Pg.1-13.

27. Purnamasari, Apriani, Sukirman, and Umi Pratiwi. 2016. Effects of Understanding, Tax Sanctions, Government Trust and Legal Levels, and Nationalism on Compliance with Taxpayers in Paying PBB-P2 (Study on PBB-P2 Taxpayers in Banjar City, West Java). National Symposium on Accounting XIX. Lampung.

28. Ratmono, Dwi and Cahyonowati, Nur. 2013. Trust in the Tax Authorities as Moderating the Effects of Deterrence Factors on Compliance with Personal Taxpayers. Indonesian Accounting Journal, Vol. 2 No. January 1, 2013, page 1-15.

29. Ratmono, Dwi. 2015. Efforts to Improve Personal Taxpayer Compliance: Explanation of the Economy Slippery Slope. Bulletin Theory, 13 (1). pp. 59-79.

30. Robbin, Stephen, P., and Timothy, A.J. 2007. Organizational Behavior. Book 2 Edition 12. Salemba Empat: Jakarta.

31. Rusdi Hidayat, Suhadak, Darminto. 2014. Model of Service Quality Measurement, Regional Tax Regulations, Taxpayer Satisfaction Level, Behavior and Compliance Using Confirmator Factor Analysis. World Applied Sciences Journal 29 (1): 56-61, 2014. Brawijaya University, Indonesia Malang.

32. Sari, Maria M. Ratna, and Ni Nyoman Afriyanti.2012. "The Influence of Taxpayer Compliance and Tax Examination on Receipt of PPH Article 25/29 Corporate Taxpayers in East Denpasar Primary KPP." No 1, Vol 7.

33. Scholz, John, T dan Lubell, M.1998.Adaptive Political Attitude: Duty, Trust, and Fear as Monitors of Tax Policy.American Journal of Political Science.42, 398-417.

34. Sellywati, Mohd Faizal, Mohd Rizal Palil, Ruhanita Maelah dan Rosiati Ramli. 2017. Perception on justice, trust and tax compliance behavior in Malaysia. 
35. Stefanos A. Tsikas. 2017. Enforce Tax Compliance, but Cautiously: The Role of Trust in Authorities and Power of Authorities. Hannover Economic Papers (HEP) No. 589 March 2017. Leibniz University Hannover, School of Economics and Management, RTG 1723 "Globalization and Development", Koenigsworther Platz 1, D30167 Hannover, Germany.

36. Tenbrunsel, A. E., dan Messick, D. M. 1999. Sanctioning systems, decision frames, and cooperation. Administrative Science Quarterly, 44, 684-707.

37. Torgler, Benno dan Schneider, F.2004.Attitudes towards paying taxes in Austria: An empirical analysis.Paper Working Yale Centre for Internasional And Area Studies, Leitner Program in Internasional and Comparative Political Economy.

38. Verboon, P dan van Dijke, M. 2011. When do severe sanctions enhance compliance? The role of procedural fairness. Journal of Economic Psychology 32 pp 120-130.

39. Wenzel, M. 2004. The social side of sanctions: Personal and social norms as moderators of deterrence. Law and Human Behavior, 28, 547-567.

40. Wijayanti, Diah Wahyu, and Noer, Sasongko. 2017. Effects of Understanding, Tax Sanctions, Government's Level of Trust and Law on Compliance in Paying Taxpayers (Taxpayer Study on Communities in Pajang SubDistrict, Laweyan Surakarta District). National Seminar and The 4th Call for Sharia Paper Accounting Professional Roles in Corruption Management. Pages 308-326. ISSN 2460-0784.

41. Yousafzai, S. Y., Pallister, J. G., dan Foxall, G. R., 2003. A Proposed Model of ETrust for Electronic Banking, Technovation, 23: 847-860.

42. Wold, H. Partial East Square. In S Kotz and NL.Johnson (Eds).1985.Encyclopedia of Statistic Science, Vol.8...pp 587-599, New York, Wiley. 